\title{
Unconfined Groundwater Flow Pattern and Facies Changes at Way Huwi Village, South Lampung
}

\section{Luhut Pardamean Siringoringo $^{1 *}$, Sandi Maulana ${ }^{1}$}

${ }^{1}$ Program Studi Teknik Geologi Institut Teknologi Sumatera

\begin{abstract}
Way Huwi Village is located in South Lampung, near the Institut Teknologi Sumatera (ITERA). The purposes of this research is to know the unconfined groundwater flow pattern and groundwater facies changes. We measured the depth of water table at nine dig wells, analyzed piper diagram for groundwater facies identification. Then, we integrated groundwater flow patterns and groundwater facies from each well to analyze groundwater facies change pattern in research area. The result indicated that the unconfined groundwater flows from SW to NE of research area, following higher (SW) to lower elevation (NE). There are six patterns of unconfined groundwater facies changes: from Facies $\mathrm{Na}-\mathrm{Cl}$ to Facies $\mathrm{Na}-\mathrm{HCO}_{3}-$ $\mathrm{Cl}$, Facies $\mathrm{Na}-\mathrm{HCO}_{3}-\mathrm{Cl}$ to Facies $\mathrm{Ca}-\mathrm{Mg}-\mathrm{HCO}_{3}$, Facies $\mathrm{Na}-\mathrm{HCO}_{3}-\mathrm{Cl}$ to Facies Na-Cl, Facies Na$\mathrm{HCO}_{3}-\mathrm{Cl}$ to Facies $\mathrm{Na}_{-} \mathrm{SO}_{4}-\mathrm{Cl}$, Facies $\mathrm{Ca}-\mathrm{Mg}$ $\mathrm{HCO}_{3}$ to Facies $\mathrm{Na}-\mathrm{SO}_{4}-\mathrm{Cl}$, and Facies $\mathrm{Ca}-\mathrm{Mg}$ $\mathrm{HCO}_{3}$ to Facies $\mathrm{Na}-\mathrm{HCO}_{3}-\mathrm{Cl}$.
\end{abstract}

Keywords: Facies Changes, Flow Pattern, Unconfined Groundwater, Piper Diagram, Lampung, Way Huwi.

ABSTRAK Pola aliran airtanah tidak tertekan dan perubahan fasiesnya di Desa Way Huwi, Lampung Selatan. Desa Way Huwi terletak di Lampung Selatan, di dekat Institut Teknologi

$\begin{array}{lr}\text { Naskah masuk } & : \text { 27 Oktober } 2019 \\ \text { Naskah direvisi } & : \\ \text { Naskah diterima } & \text { 17 Juni } 2020 \\ & \text { 17 Juni } 2020\end{array}$

* Corresponding Author.

Email : luhut.pardamean@gl.itera.ac.id
Sumatera (ITERA). Tujuan dari penelitian ini adalah untuk mengetahui perubahan pola aliran airtanah dan fasies airtanah yang terjadi. Kami mengukur kedalaman muka airtanah pada sembilan sumur gali, menganalisis Diagram Piper untuk mengetahui fasies airtanah. Kemudian kami mengintegrasikan pola aliran airtanah dan fasies airtanah setiap sumur untuk mengetahui pola perubahan fasies air tanah. Hasil analisa menunjukkan bahwa airtanah tidak tertekan mengalir dari Barat Daya ke Timur Laut mengikuti ketinggian yang lebih tinggi $(S W)$ ke ketinggian yang lebih rendah (NE). Ada enam pola perubahan fasies airtanah tidak tertekan: dari Facies $\mathrm{Na}$-Cl ke Facies $\mathrm{Na}-\mathrm{HCO}_{3}-\mathrm{Cl}$, Facies $\mathrm{Na}-\mathrm{HCO}_{3}-\mathrm{Cl}$ ke Facies $\mathrm{Ca}-\mathrm{Mg}-\mathrm{HCO}_{3}$, Facies $\mathrm{Na}$ $\mathrm{HCO}_{3}-\mathrm{Cl}$ ke Facies $\mathrm{Na}$ - $\mathrm{Cl}$, Facies $\mathrm{Na}-\mathrm{HCO}_{3}-\mathrm{Cl}$ ke Facies $\mathrm{Na}-\mathrm{SO}_{4}-\mathrm{Cl}$, Facies $\mathrm{Ca}-\mathrm{Mg}-\mathrm{HCO}_{3}$ ke Facies $\mathrm{Na}-\mathrm{SO}_{4}-\mathrm{Cl}$, dan Facies $\mathrm{Ca}-\mathrm{Mg}-\mathrm{HCO}_{3}$ ke Facies $\mathrm{Na}-\mathrm{HCO}_{3}-\mathrm{Cl}$

Kata kunci: Perubahan Fasies, Pola Aliran, Airtanah Tidak Tertekan, Piper Diagram, Lampung, Way Huwi

\section{INTRODUCTION}

Way Huwi Village is located in front of the ITERA campus. This village is one of the places for ITERA students to stay. This village will continue to grow as the demand for student residences increases. Expanding residences will lead to increasing the groundwater pumping. In order for better controlled the village development, it is indispensable to know the pattern of groundwater flows and facies changes. The pattern of groundwater flow is related to the quantity, and changes in groundwater facies (hydrochemical) related to quality of the water. The $3.1 \mathrm{~km}^{2}$ study area is composed of quarterly volcanic deposits (Mangga, S.A; Amirudin; Suwarti, T; Gafoer, 1993). These volcanic deposits affect the chemical content of groundwater as well as being influenced. 


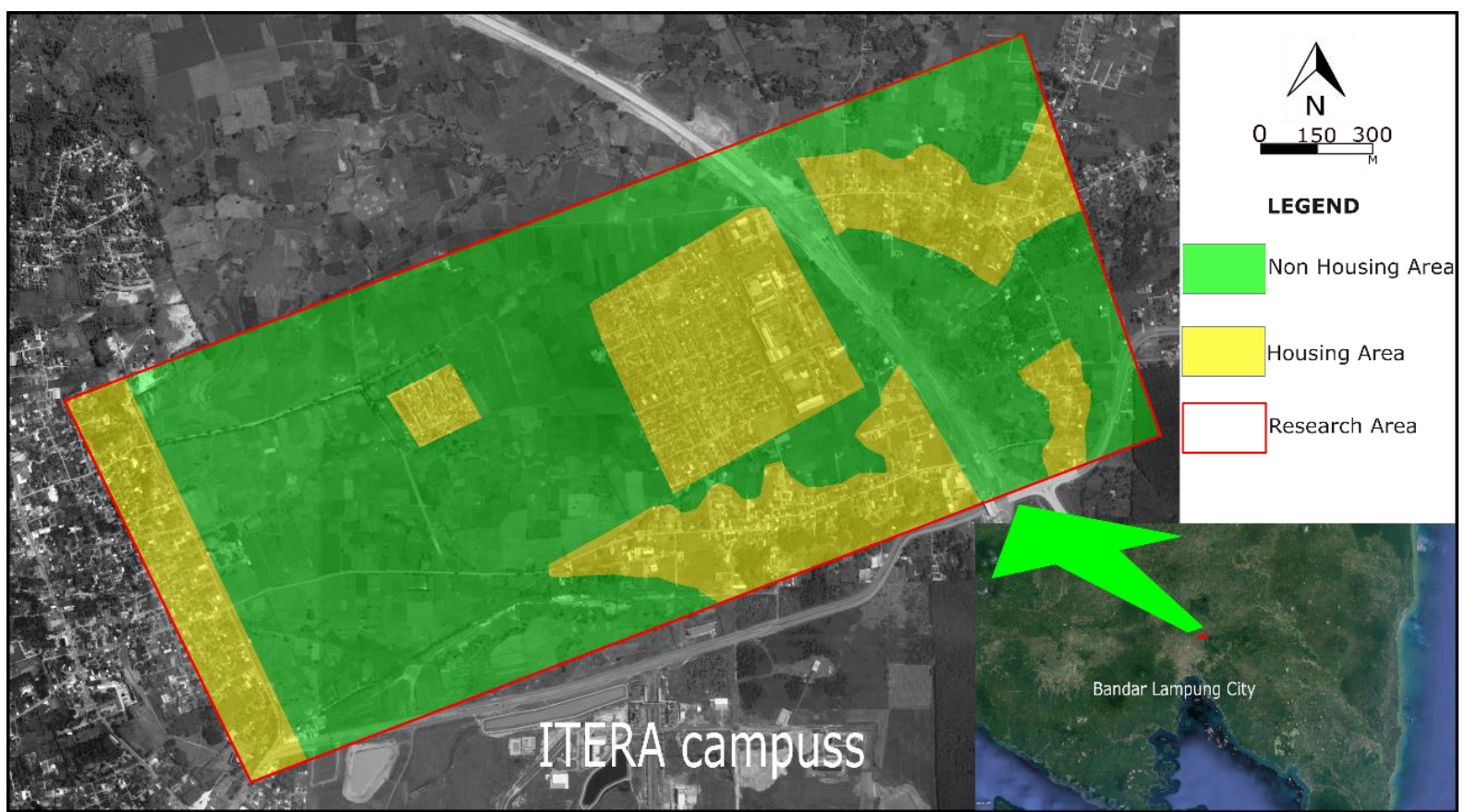

Figure 1. Distribution of housing and non-housing at research area

Besides rock factors, weather also determine the groundwater chemistry (Pazand et al., 2018). There are two types of weathering: chemical weathering and physical weathering. Chemical weathering is resulted from chemical reactions between minerals in rocks and external agents such as air or water. Oxygen oxidizes minerals to alteration products, whereas water can convert minerals to clays or dissolve minerals completely. Physical weathering is when rocks are broken apart by mechanical processes such as rock fracturing, freezing and thawing, or breakage during transport by rivers or glaciers (Houston, 2001). This research focused on weathering caused by chemical reactions.

The Google Earth satellite map shows that the housing has not been evenly distributed in the research area (Figure 1). The rest of the land is used for plantations and livestock. This condition has an effect to the diversity of the groundwater types in the research area. In addition, the uneven morphology of the area will also affect the direction of groundwater flow patterns, especially the unconfined aquifer groundwater flow. We assumed that the unconfined groundwater flow patterns follow the elevation gradient, which is flowing from the higher to the lower elevation.

Along the course of the flow, groundwater interacts with the rocks. The degree of weathering of rocks will affects the chemical content of groundwater (Dhanwinder-singh, 2011). The dominant elements will determine the type of groundwater facies based on groundwater samples. It will be reflected in the Piper diagram. So far, the Piper diagram is one of the best methods that describe the chemical characteristics of groundwater (Yang et al., 2016). The object of this study is the shallow groundwater from dig wells. The purpose is to know the flow and the changes in facies that might occur in the research area. The result provides a general description of the pattern of the groundwater flow and the course of facies changes from one well to another.

\section{GEOLOGY AND HYDROGEOLOGY}

The research area located inside Tanjungkarang sheet regional geology map scale 1:250.000 (Mangga, S.A; Amirudin; Suwarti, T; Gafoer, 1993). The area composed of Lampung Formation of Quaternary age (Figure 2). The Lampung formation composed of volcanic activity deposits like pumice tuff, rhyolitic tuff, tuff unified tuffit, tuffaceous claystone, and tuffaceous sandstone. Lampung Formation is deposited unconformity above the Andesite of Tertiary age. Above 


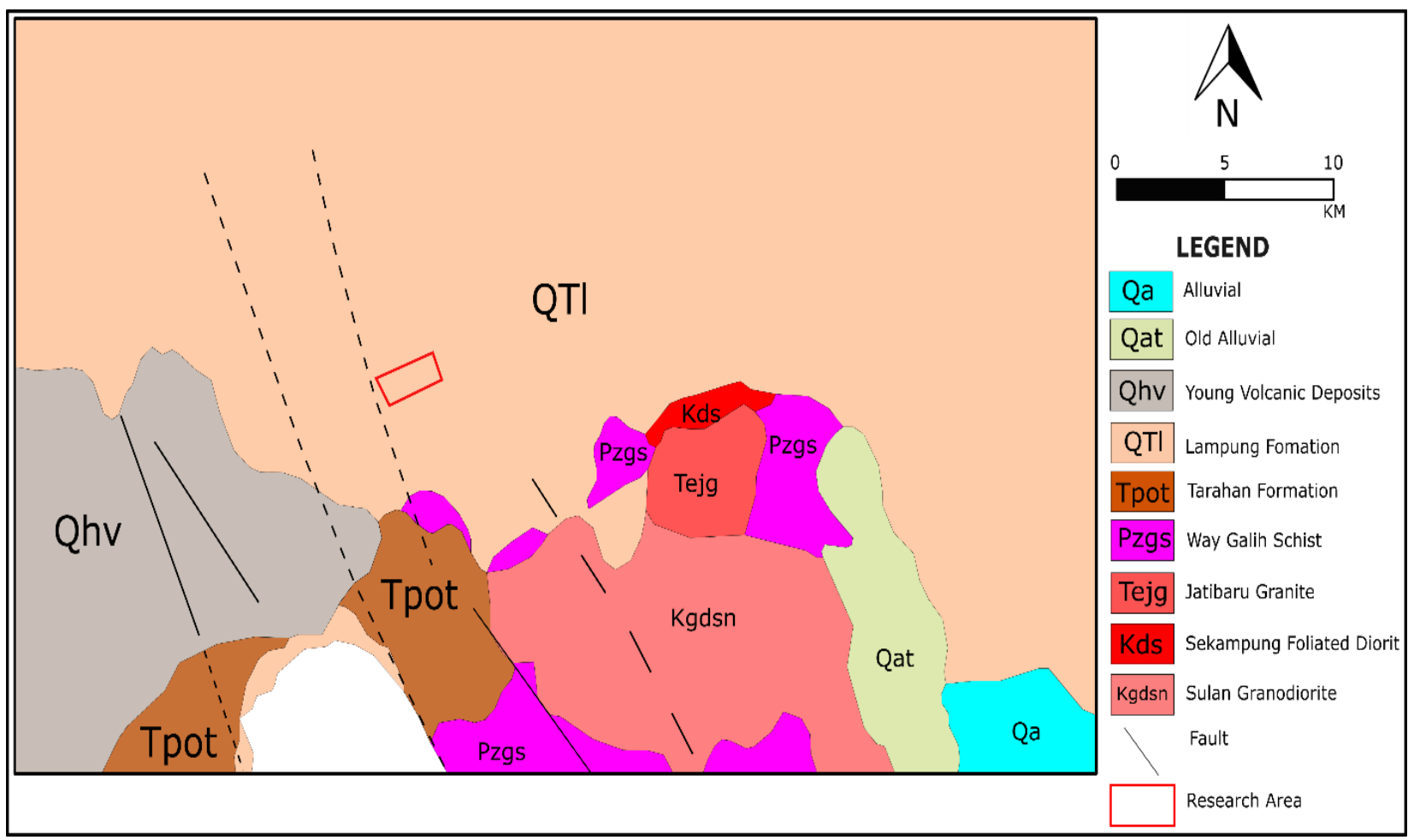

Figure 2. The geological map of research area (modified from Mangga, 1993)

Lampung Formation, deposited unconformity young volcanic deposits (lava andesite-basalt, breccia, and tuff).

The research area is within Metro-Kotabumi Groundwater Basin (Yudhoyono, 2011). Hydrogeology of the area indicates the ability to release water at low-medium stage. It is locally productive due to thetuff aquifer (Setiadi, H; Ruhijat, 1993).

\section{METHODS}

This research used three stages of analysis. First was measuring the depth of water table at each dig wells, including measured the elevation of the well. Second, we analyzed groundwater facies based on groundwater samples from each dig well. And third, we compared the changes in groundwater facies by integrating the results of depth of water table with the results of the Piper diagram analysis on each well.

For the first step, we prepared clean topless glasses $2000 \mathrm{ml}$ to collect water. Then we used $1000 \mathrm{ml}$ polypropylene bottles as temporary storage media before groundwater samples were analyzed at the laboratory (Badan Standarisasi Nasional, 2008). Samples were analyzed in the Water Quality Laboratory of the Faculty of Civil and
Environmental Engineering (ITB) using the standard methods for The Examination of Water and Wastewater 22nd Edition 2012 (APHA).

We used a marked rope for measuring the depth of water table. In mapping and data processing, we used Google Earth Pro, Excel, Surfer, and Inkscape.

\section{RESULT AND DISCUSSION}

\section{Groundwater Flow Pattern}

Observations and sampling of water had been carried out on nine dig wells (Figure 3). The depth of water table ranges from $5.6 \mathrm{~m}$ to $0.2 \mathrm{~m}$. The highest elevation is $129 \mathrm{~m}$ and the lowest is $98 \mathrm{~m}$ (Table 1). From the near surface water tables, we assumed that the surface pressure of the water table is similar to the atmospheric pressure.

On the other hand, surface geological mapping indicated that lithology of the area is composed of tuff (Figure 4). The absence of siltstone or claystone at the top of tuff indicates that the tuff layer is an unconfined aquifer.

The depth of shallow water tables in the unconfined aquifer could be estimated to be close to the well elevation. Assuming that the changes 


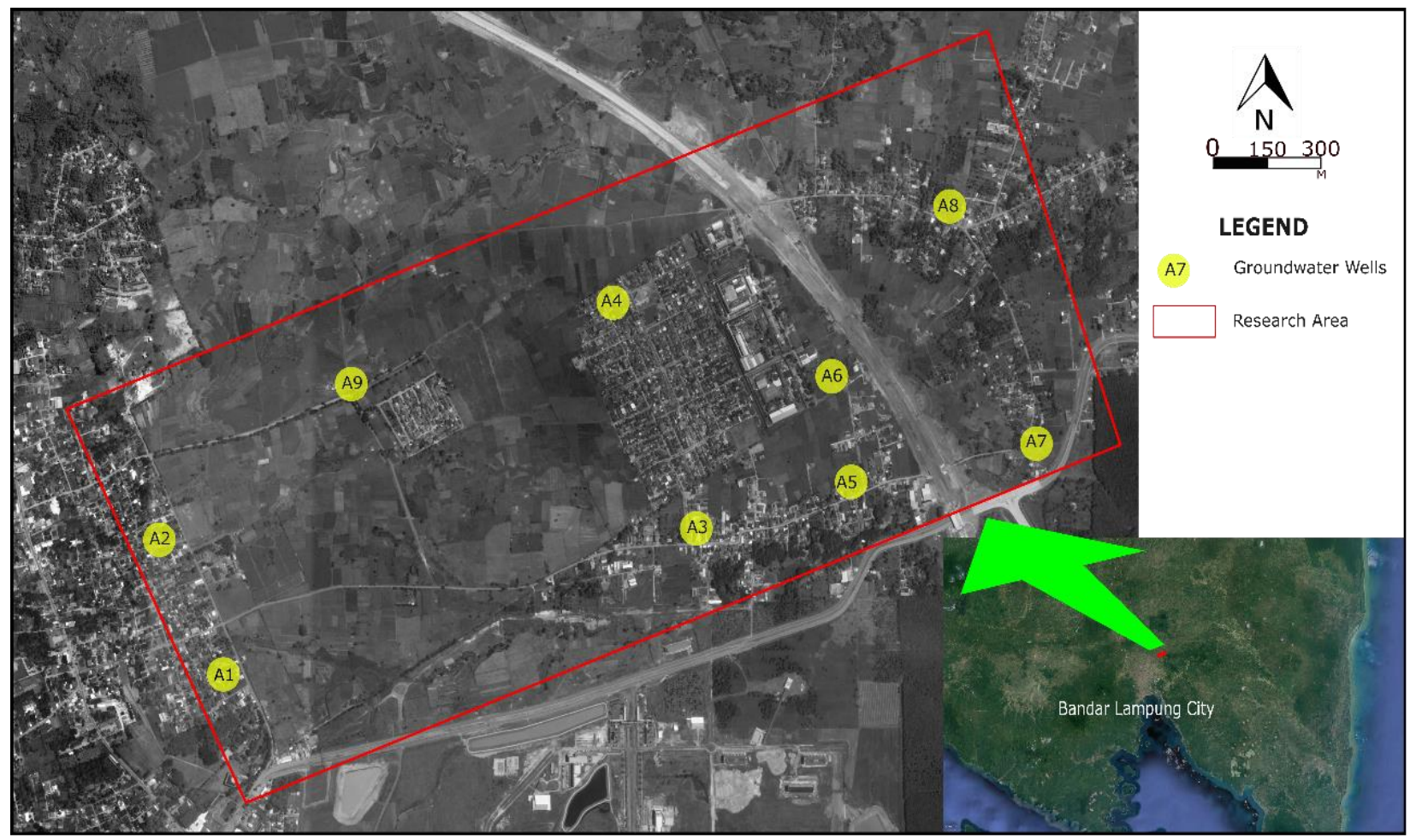

Figure 3. The locations of groundwater sampling

in the depth of the water table are due to the changes in elevation. To verify this assumption, graphs in Figure 5 compares the well elevation and the depth of water table at each well.

Figure 5 shows two graphs. The orange graph (above) shows the increase of well elevation from the well A7 towards the well A2. The blue graph (below) shows the increase of the depth of the water table from the well A7 towards the well A2. The two graphs comparison indicates that changes in the water table depth follow the changes in well elevation. In other words, the higher the elevation of the well, the deeper the water table.

After the relationship between the elevation of the well and the depth of the groundwater level was defined, the next step is to map the groundwater flow pattern to determine the direction of the flow. The groundwater flow pattern map (Figure 6) suggests that the unconfined groundwater flows from southwest to the northeast. Therefore, in quantity, that the highest unconfined groundwater supply and groundwater resources are in the northeast part of the research area.

After the relationship between the elevation of the well and the depth of the groundwater level was defined, the next step is to map the groundwater flow pattern to determine the direction of the flow.

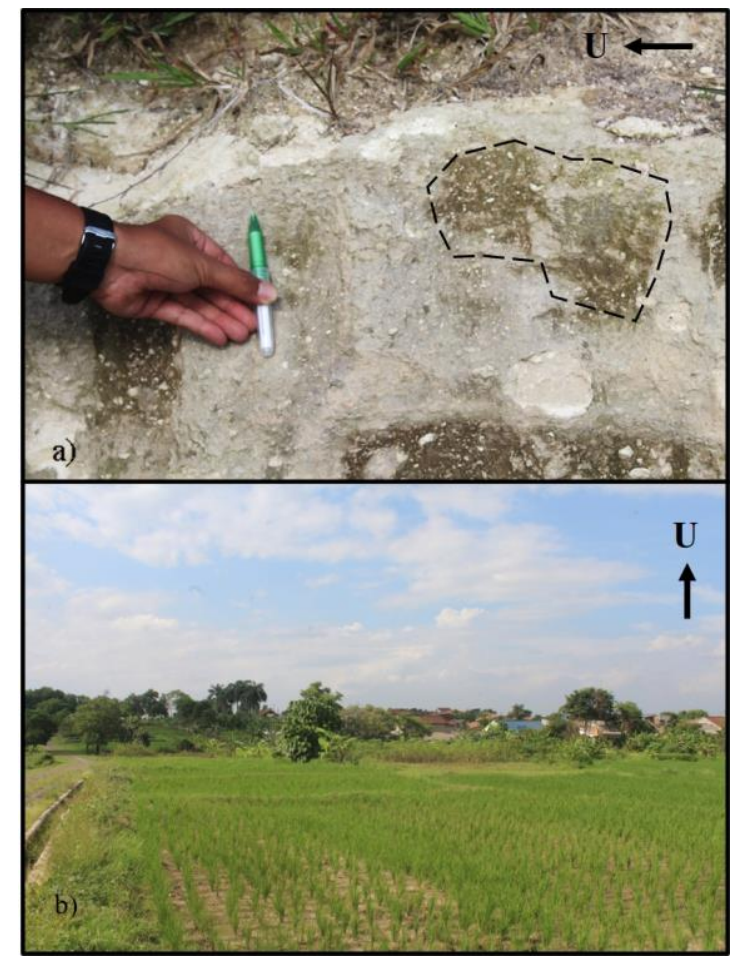

Figure 4. a) A tuff outcropped near A9 well with weathering process (dash lines). b) Rice field also near A9 well 


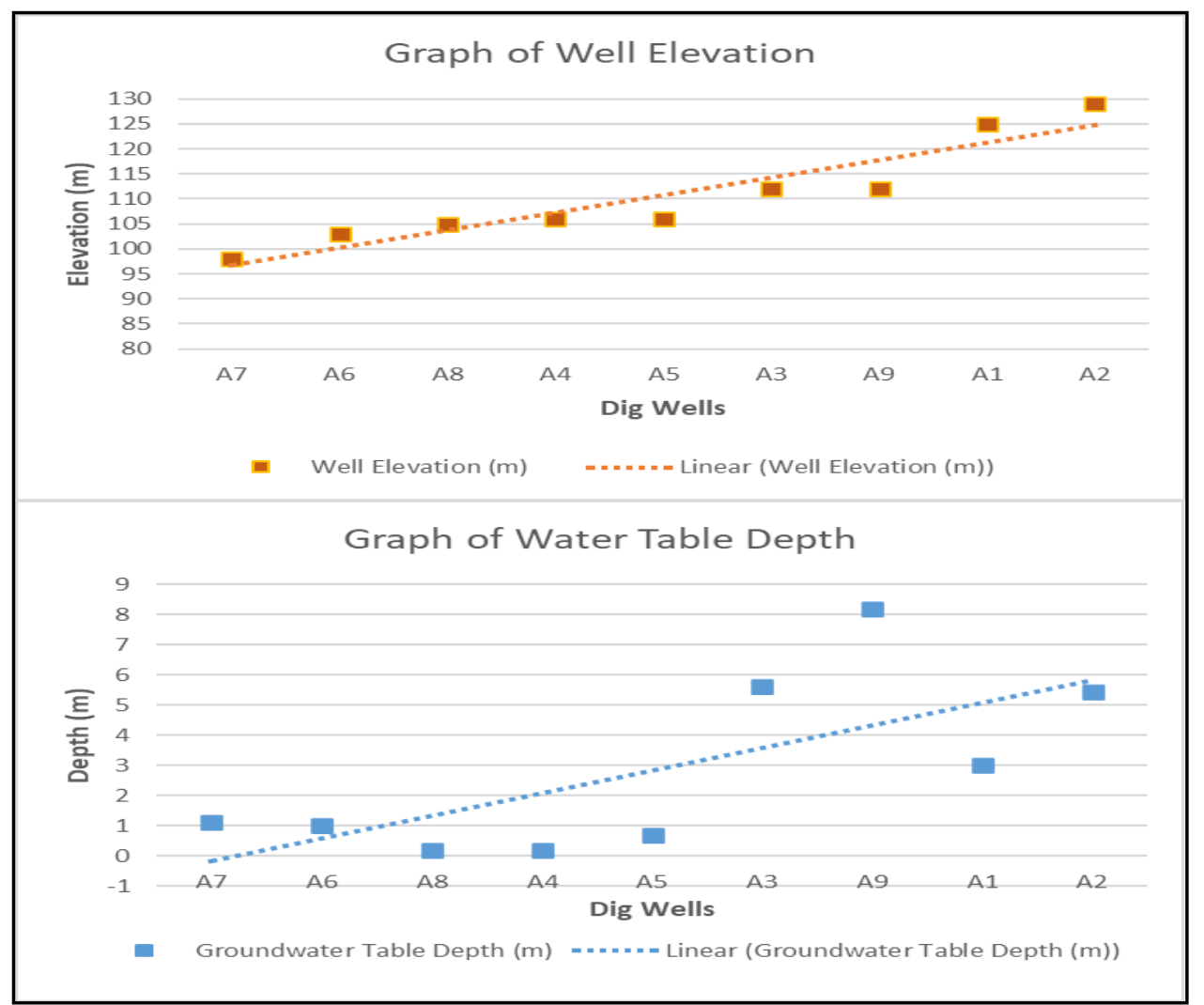

Figure 5. Relationship between graph of well elevation and groundwater table depth

The groundwater flow pattern map (Figure 6) suggests that the unconfined groundwater flows from the southwest to the northeast. Therefore, in quantity, that the highest unconfined groundwater supply and groundwater resources are in the northeast part of the research area.

\section{Groundwater Facies \& Facies Changes}

There are four groundwater facieses in the research area based on the plotting of cation and anion data into the Piper Diagram (Figure 7). The

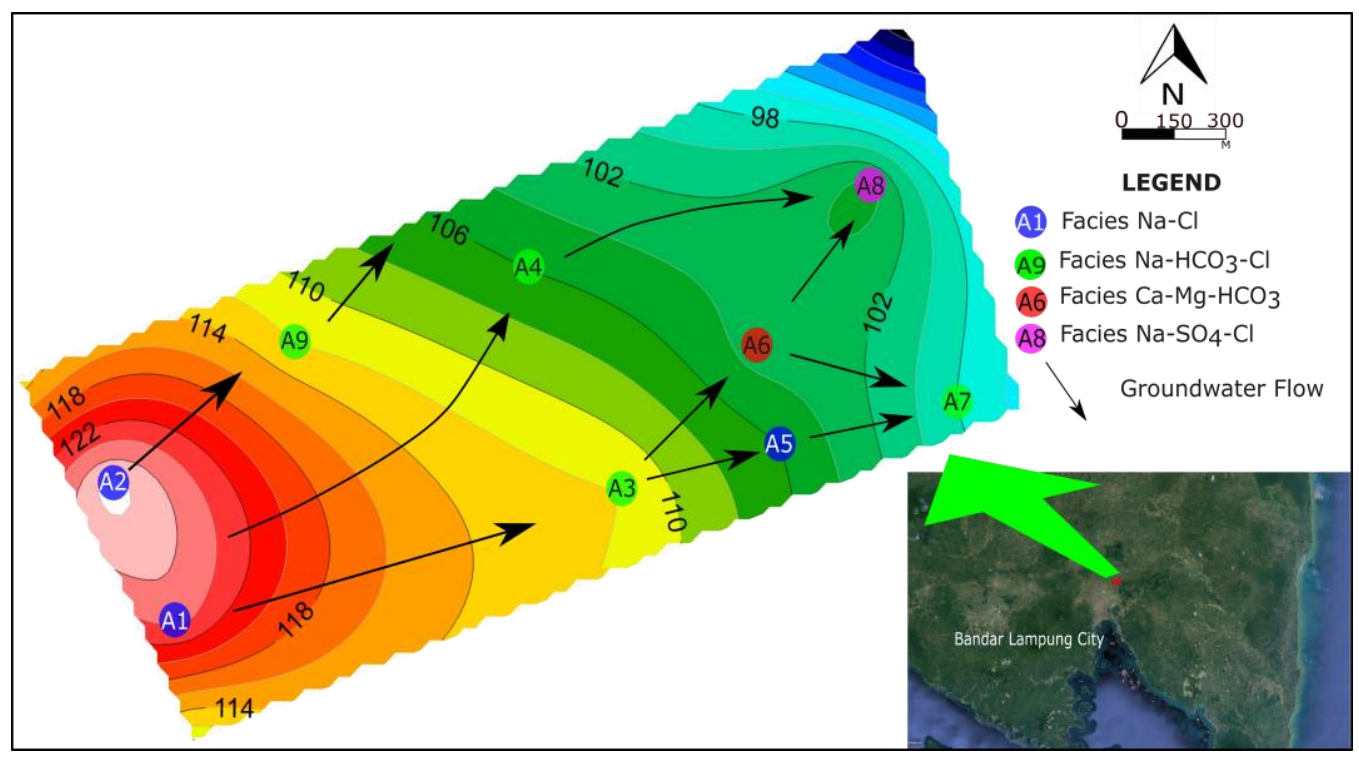

Figure 6. Distribution of Groundwater facieses at research area 
facieses are facies $\mathrm{Na}-\mathrm{Cl}$, facies $\mathrm{Na}-\mathrm{HCO}_{3}-\mathrm{Cl}$, facies $\mathrm{Ca}-\mathrm{Mg}-\mathrm{HCO}_{3}$, facies $\mathrm{Na}-\mathrm{SO}_{4}-\mathrm{Cl}$.

During the groundwater flow, the changes in the groundwater facies occur. The explanation is as follows:

$$
\mathrm{Na}-\mathrm{Cl} \rightarrow \mathrm{Na}-\mathrm{HCO}_{3}-\mathrm{Cl}
$$

Facies $\mathrm{Na}-\mathrm{Cl}$ mostly in residential areas (Figure 3 and 6). Residential areas that are closely related to anthropogenic activity contribute to increased Cland $\mathrm{Na}+$ concentrations (Kut et al., 2018). The increase in the value of these ions can also come from silicate weathering (Edet, Anieken; Worden, 2009; Zhang et al., 2015). Previous research using Gibbs plot method had suggested that the mechanism controlling ion $\mathrm{Cl}$ concentration is rock weathering domination (Siringoringo et al., 2019). These silicates mineral are albite minerals to Na-montmorillonite and anorthite to $\mathrm{Ca}$ montmorillonite (Esteller et al., 2017). Referring to regional geology, the research area is composed of volcanic deposits consisting of tuff lithology. So, with this information, the origin of $\mathrm{Na}$ and $\mathrm{Cl}$ ions might be from silicate weathering and anthropogenic activity. During groundwater flowing, $\mathrm{HCO}_{3}$ ions is added.
The sampling points $\mathrm{A} 9, \mathrm{~A} 4$, and $\mathrm{A} 3$ are around the community's rice fields. We assumed that $\mathrm{CO}_{2}$, which is an $\mathrm{HCO}_{3}$ ion-forming compound, is derived from plant respiratory activity. This compound then diffuses into groundwater and produces $\mathrm{HCO}_{3}$.

From the facies change (1) also shows contrasting variation in $\mathrm{EC}$ and $\mathrm{pH}$ values. Facies $\mathrm{Na}-\mathrm{Cl}$, which have acidic properties, become facies $\mathrm{Na}-$ $\mathrm{HCO}_{3}-\mathrm{Cl}$, which are alkaline. This is also followed by a decrease in EC values of around $100-150 \mathrm{mV}$ (Table 1). This acidic property comes from the release of $\mathrm{H}$ ions from decomposed $\mathrm{HCl}$ compounds. While the alkaline properties come from the addition of water along groundwater flows, which lowers acidity of facies $\mathrm{Na}-\mathrm{Cl}$. The decrease in $\mathrm{EC}$ value is caused when groundwater flows, groundwater dissolves Nitrates and Phosphates compounds. This compound is a chemical compound from fertilizer.

$\mathrm{Na}-\mathrm{HCO}_{3}-\mathrm{Cl} \rightarrow \mathrm{Na}-\mathrm{SO}_{4}-\mathrm{Cl}$

From facies $\mathrm{Na}-\mathrm{HCO}_{3}-\mathrm{Cl}$, groundwater facies change to facies $\mathrm{Na}_{-} \mathrm{SO}_{4}-\mathrm{Cl}$. The position of the $\mathrm{HCO}_{3}$ ion is substituted by $\mathrm{SO}_{4}$ ions. This dominant $\mathrm{SO}_{4}$ ion is due to the oxidation of the

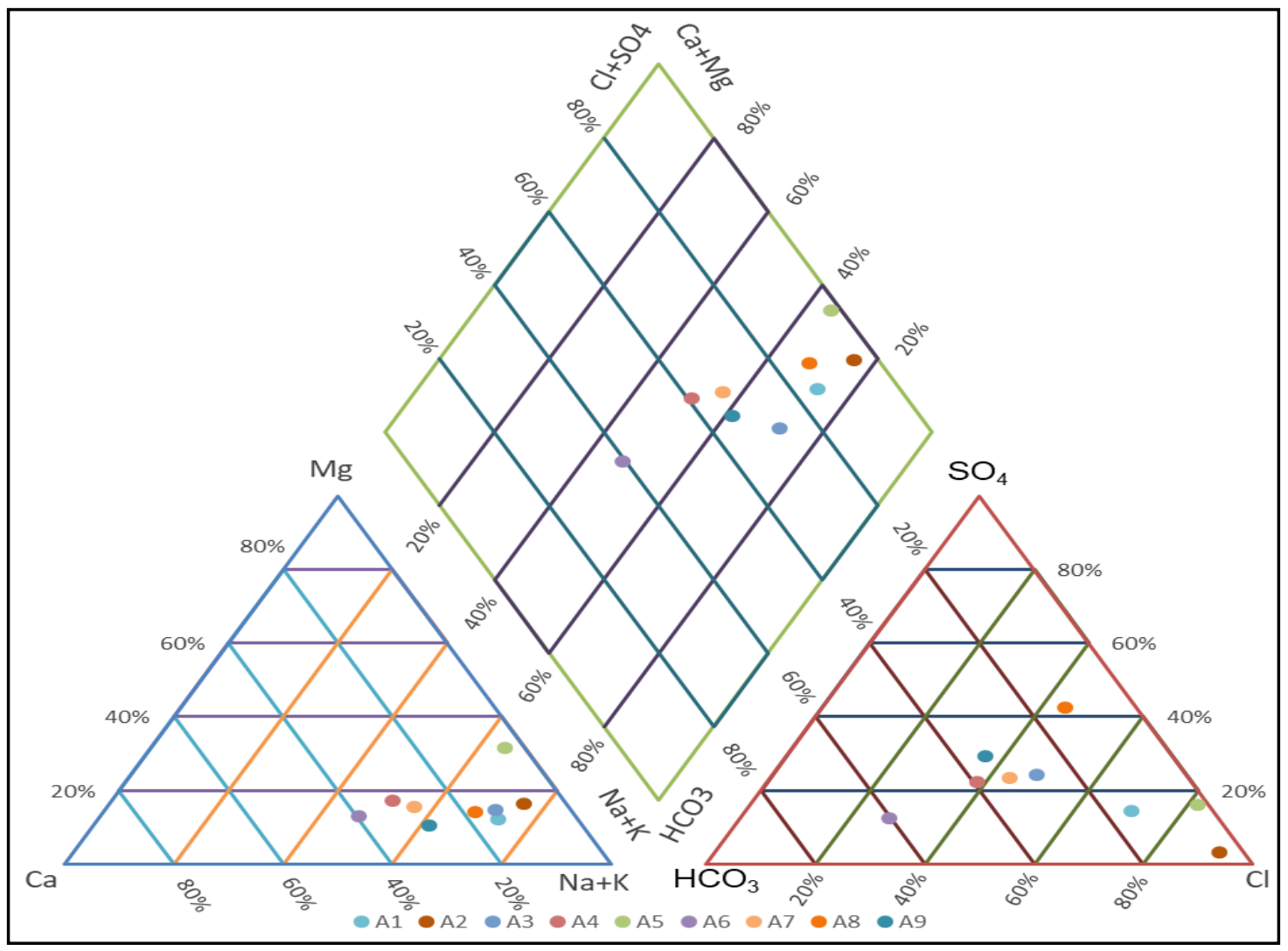

Figure 7. Piper diagram based on cation and anion compositions of groundwater in research area 


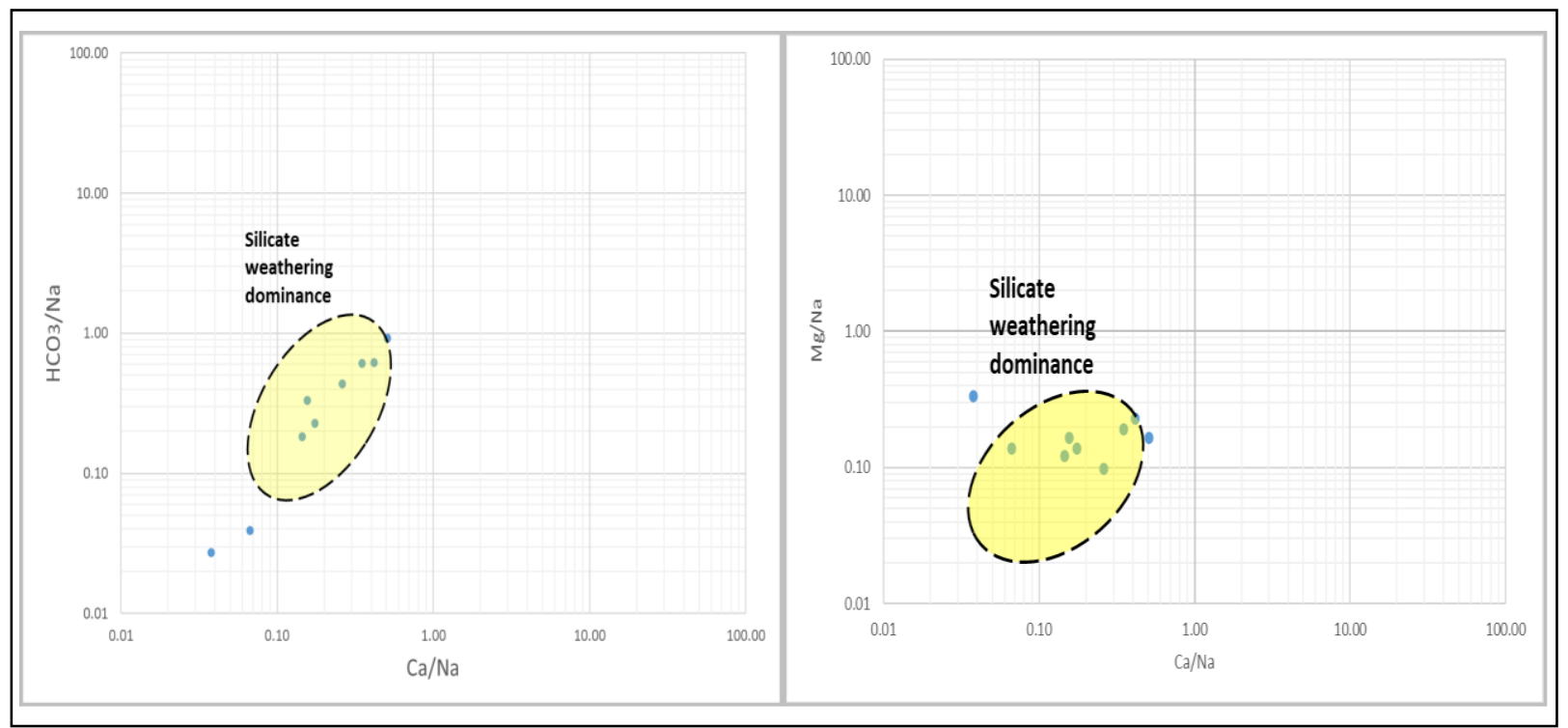

Figure 8. Molar ratio bivariate plots of Na-normalized $\mathrm{Ca}$ and $\mathrm{HCO}_{3}$ and $\mathrm{Na}$-normalized $\mathrm{Ca}$ and $\mathrm{Mg}$

Pyrite mineral. At the same time, the oxidation of the pyrite mineral also produces $\mathrm{Cl}$ - ions (Zaidi et al., 2016; Zhang et al., 2015). Pyrite minerals can be found in igneous rocks, sedimentary rocks, and metamorphic rocks but in limited quantities. Ion $\mathrm{Na}$ and $\mathrm{Cl}$ are still sourced from anthropogenic activities and silicate mineral weathering. The oxidations reactions of pyrite mineral as follow:

$$
\mathrm{FeS}_{2}+\frac{7}{2} \mathrm{O}_{2}+\mathrm{H}_{2} \mathrm{O}=\mathrm{Fe}^{+}+2 \mathrm{SO}_{4}^{2-}+2 \mathrm{H}^{+}
$$

Changes in facies (2) were also followed by decreases in EC values (Table 1). It means that the ability of groundwater in flowing electricity has reduced. This is caused during flowing, groundwater dissolves Nitrates and Phosphates.

$$
\mathrm{Na}-\mathrm{HCO}_{3}-\mathrm{Cl} \rightarrow \mathrm{Ca}-\mathrm{Mg}-\mathrm{HCO}_{3}
$$

From facies $\mathrm{Na}-\mathrm{HCO}_{3}-\mathrm{Cl}$, groundwater facies change to facies $\mathrm{Ca}-\mathrm{Mg}-\mathrm{HCO}_{3}$. The $\mathrm{HCO}_{3}$ ions still exist indicate that the influence of $\mathrm{CO}_{2}$ is still dominant. As seen in figure 3 and 6, the sampling point (A6) is around the rice fields. Substitution of $\mathrm{Na}$ and $\mathrm{Cl}$ ions by $\mathrm{Ca}$ and $\mathrm{Mg}$ ions shows that the effect of weathering of silicate minerals gives an increase in the value of $\mathrm{Ca}$ and $\mathrm{Mg}$ ions (Esteller et al., 2017; Zhang, Jin, Yu, Zhou, \& Zhou, 2015). The silicate minerals are like anothorite, pyroxene, and amphibole (Edet, Anieken; Worden, 2009). From the facies change (3) also shows changes in $\mathrm{EC}$ and $\mathrm{pH}$ values table 1 ).
$\mathrm{pH}$ value decreasing is not extreme as facies changes on number 1 . The difference is about 0.5 point lower.

The cause of the stability of the $\mathrm{pH}$ value on changes in facies is allegedly due to the location that is surrounded by rice fields and does not get significant additional water volume from other sources. The decrease in EC value is caused by groundwater flows. Groundwater dissolves nitrates and phosphates compounds. This compound is a chemical compound from fertilizer. A couple of methods were used to find the control of the ion exchange process. First, using Gibbs plot from previous research concluded that the rock weathering is dominate. Second, using Molar ratio bivariate plots from Gaillardet (Gaillardet et al., 1999) suggested that the weathering type is silicate (Figure 8).

$\mathrm{Ca}-\mathrm{Mg}-\mathrm{HCO}_{3} \rightarrow \mathrm{Na}-\mathrm{SO}_{4}-\mathrm{Cl}$

From facies $\mathrm{Ca}-\mathrm{Mg}-\mathrm{HCO}_{3}$, the groundwater facies change to facies $\mathrm{Na}_{-} \mathrm{SO}_{4}-\mathrm{Cl}$. This facies change is a total change because all ions are replaced by new ions. This change is not due to drastic environmental changes. From previous explanations, $\mathrm{Ca}, \mathrm{Mg}, \mathrm{Na}$, and $\mathrm{Cl}$ ions are caused by weathering of silicate minerals. To validate this, we used the $\mathrm{Na} / \mathrm{Cl}$ bivariate method to understand the exchange process between $\mathrm{Na}$ and $\mathrm{Cl}$ ion. Figure 9 shows that $\mathrm{Na}$ ion is more dominant than $\mathrm{Cl}$ ion. This signifies that the type of weathering is silicate rocks weathering (Meybeck, 1987). 
Table 1. Physical and chemistry data from all wells

\begin{tabular}{|c|c|c|c|c|c|c|c|c|c|c|}
\hline $\begin{array}{l}\text { Samples } \\
\text { Code }\end{array}$ & $\begin{array}{c}\text { Water } \\
\text { Table } \\
\text { Depth } \\
\text { (m) }\end{array}$ & $\begin{array}{c}\text { Elevation } \\
\text { (m) }\end{array}$ & $\begin{array}{c}\mathbf{E C} \\
(\mu \mathrm{S} / \mathrm{cm})\end{array}$ & $\begin{array}{c}\text { TDS } \\
(\mathrm{mg} / \mathrm{L})\end{array}$ & $\begin{array}{c}\mathrm{Fe} \\
(\mathrm{mg} / \mathrm{L})\end{array}$ & $\begin{array}{c}\mathbf{F} \\
(\mathrm{mg} / \mathrm{L})\end{array}$ & pH & $\begin{array}{c}\mathrm{Mn} \\
(\mathrm{mg} / \mathrm{L})\end{array}$ & $\begin{array}{c}\mathrm{KMnO4} \\
(\mathrm{mg} / \mathrm{L})\end{array}$ & $\begin{array}{c}\mathrm{NO}_{3} \\
(\mathrm{mg} / \mathrm{L})\end{array}$ \\
\hline$\overline{\mathrm{A} 1}$ & 3 & 3 & 433 & 259 & 0,01 & 0.543 & 5.86 & $<0,2$ & 6.81 & 45.2 \\
\hline A2 & 5.45 & 5.45 & 365 & 219 & 0.01 & 0.063 & 5.3 & 0.458 & 4.36 & 59.8 \\
\hline A3 & 5.6 & 5.6 & 752 & 526 & 0.045 & 0.273 & 7.1 & $<0,2$ & 6.81 & 55.7 \\
\hline A4 & 0.2 & 0.2 & 248 & 149 & 1.04 & 0.123 & 6.43 & $<0,2$ & 10.5 & 7.41 \\
\hline A5 & 0.7 & 0.7 & 778 & 545 & 0.01 & 0.255 & 5.54 & 1,11 & 21.8 & 114 \\
\hline A6 & 1 & 1 & 222 & 155 & 0.01 & 0.162 & 6.53 & $<0,2$ & 5.76 & 6.85 \\
\hline A7 & 1.1 & 1.1 & 535 & 375 & 0.232 & 0.255 & 6.5 & $<0,2$ & 10.8 & 22.7 \\
\hline A8 & 0.2 & 0.2 & 138 & 83 & 0.581 & 0.233 & 6.64 & $<0,2$ & 4.15 & 5.45 \\
\hline A9 & 8.2 & 8.2 & 326 & 228 & 0.01 & 0.181 & 6.58 & $<0,2$ & 11.3 & 25.9 \\
\hline $\begin{array}{c}\mathrm{NO}_{2} \\
(\mathrm{mg} / \mathrm{L})\end{array}$ & $\begin{array}{c}\mathrm{Cl} \\
(\mathrm{mg} / \mathrm{L})\end{array}$ & $\begin{array}{c}\mathrm{SO}_{4} \\
(\mathrm{mg} / \mathrm{L})\end{array}$ & $\mathrm{K}(\mathrm{mg} / \mathrm{L})$ & $\begin{array}{c}\mathrm{Na} \\
(\mathrm{mg} / \mathrm{L})\end{array}$ & $\begin{array}{c}\mathrm{Ca} \\
(\mathrm{mg} / \mathrm{L})\end{array}$ & $\begin{array}{c}\mathrm{Mg} \\
(\mathrm{mg} / \mathrm{L})\end{array}$ & $\begin{array}{c}\mathrm{CO}_{3} \\
(\mathrm{mg} / \mathrm{L})\end{array}$ & $\begin{array}{l}\mathrm{HCO}_{3} \\
(\mathrm{mg} / \mathrm{L})\end{array}$ & $\begin{array}{l}\mathrm{CaCO}_{3} \\
(\mathrm{mg} / \mathrm{L})\end{array}$ & Facies \\
\hline 0.3 & 57.7 & 15.9 & 34.5 & 43.5 & 11 & 5.6 & 0 & 21.1 & 50.5 & $\mathrm{Na}-\mathrm{Cl}$ \\
\hline 0.006 & 58.6 & 2.76 & 22 & 47.1 & 5.48 & 6.82 & 0 & 4.9 & 42 & $\mathrm{Na}-\mathrm{Cl}$ \\
\hline 0.004 & 70.6 & 48 & 81.7 & 78 & 21.1 & 13.6 & 0 & 69 & 110 & $\mathrm{Na}-\mathrm{HCO}_{3}-\mathrm{Cl}$ \\
\hline 0.004 & 22.9 & 17.8 & 6.43 & 24.9 & 15.2 & 5.05 & 0 & 40.2 & 59 & $\mathrm{Na}-\mathrm{HCO}_{3}-\mathrm{Cl}$ \\
\hline 0.665 & 133 & 35.7 & 48.3 & 77.4 & 5.1 & 27.3 & 0 & 5.64 & 126 & $\mathrm{Na}-\mathrm{Cl}$ \\
\hline 0.004 & 12.9 & 7.89 & 7.26 & 20 & 17.7 & 3.5 & 0 & 49.3 & 59 & $\begin{array}{c}\mathrm{Ca}-\mathrm{Mg}- \\
\mathrm{HCO}_{3}\end{array}$ \\
\hline 0.117 & 53.9 & 38.8 & 47 & 41.9 & 30.3 & 10.1 & 0 & 69 & 118 & $\mathrm{Na}-\mathrm{HCO}_{3}-\mathrm{Cl}$ \\
\hline 0.004 & 16.6 & 21.5 & 7.64 & 13.9 & 4.21 & 2.02 & 0 & 8.45 & 19 & $\mathrm{Na}-\mathrm{SO}_{4}-\mathrm{Cl}$ \\
\hline 0.073 & 27.8 & 30.3 & 9.22 & 38.9 & 17.7 & 4.04 & 0 & 45.1 & 61 & $\mathrm{Na}-\mathrm{HCO}_{3}-\mathrm{Cl}$ \\
\hline
\end{tabular}

The only small difference is the substitution of the $\mathrm{HCO}_{3}$ ion with $\mathrm{SO}_{4}$. Changes in the environment from rice fields to residences make the effect of $\mathrm{CO}_{2}$ reduced. And due to the oxidation of pyrite minerals, $\mathrm{SO}_{4}$ ions become more dominant. The decrease in EC value is caused by groundwater flows, when the flow dissolves nitrates and phosphates compounds.

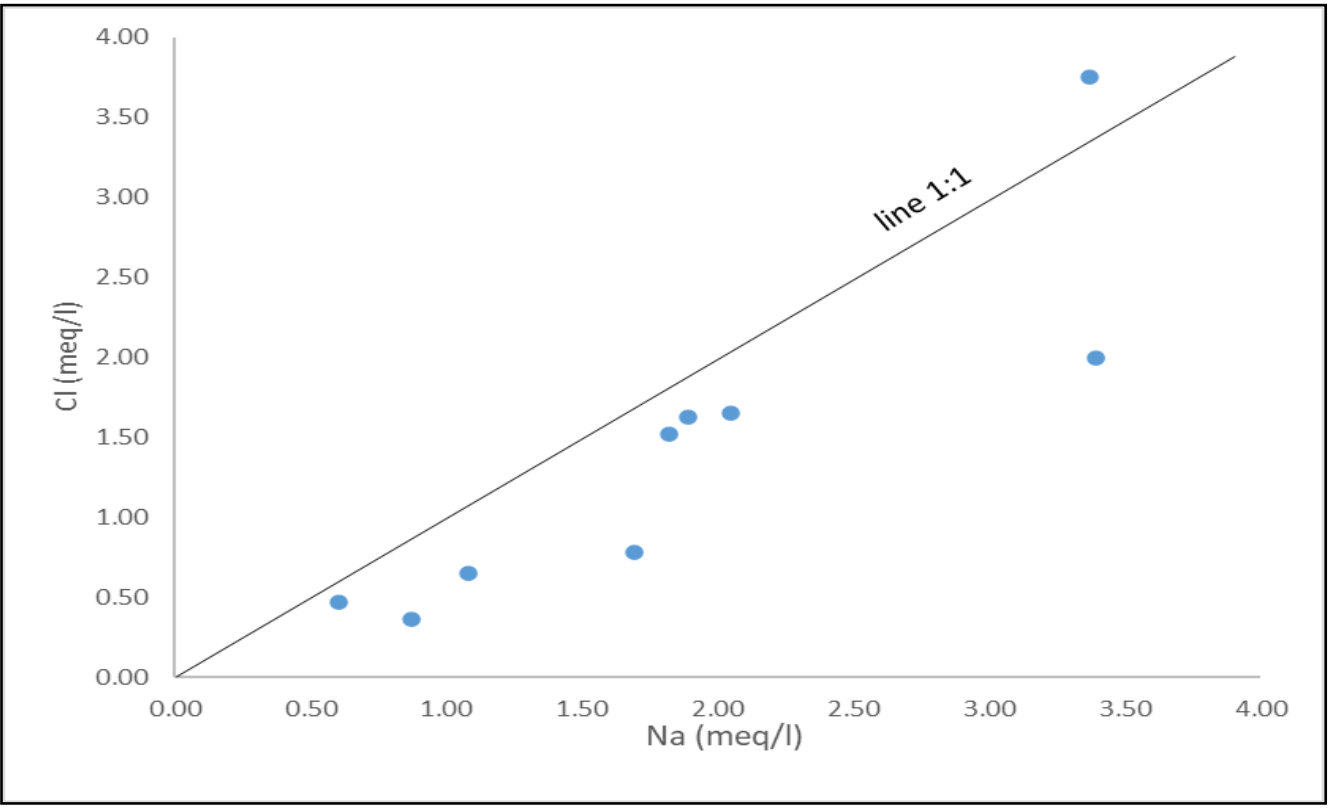

Figure $9 . \mathrm{Na} / \mathrm{Cl}$ bivariate plots diagram 
$\mathrm{Ca}-\mathrm{Mg}-\mathrm{HCO}_{3} \rightarrow \mathrm{Na}-\mathrm{HCO}_{3}-\mathrm{Cl}$

From facies $\mathrm{Ca}-\mathrm{Mg}-\mathrm{HCO}_{3}$ groundwater facies change to facies $\mathrm{Na}-\mathrm{HCO}_{3}-\mathrm{Cl}$. Basically there are no significant environmental changes. As previous facies changes, $\mathrm{Ca}, \mathrm{Mg}, \mathrm{Na}$, and $\mathrm{Cl}$ ions are caused by weathering of silicate minerals (Figure 7 dan 6), and $\mathrm{HCO}_{3}$ ions due to plant respiratory activity originating from rice fields.

$$
\mathrm{Na}-\mathrm{HCO}_{3}-\mathrm{Cl} \rightarrow \mathrm{Na}-\mathrm{Cl}
$$

In the groundwater facies change from facies $\mathrm{Na}-$ $\mathrm{HCO}_{3}-\mathrm{Cl}$ to facies $\mathrm{Na}-\mathrm{Cl}$, the absence of $\mathrm{HCO}_{3}$ ions indicates that there is a drastic change in the environment. Groundwater flows from the rice fields to the residential environment. The weathering of silicate minerals dominates the changes in groundwater facies. EC changes value is stable but not for $\mathrm{pH}$. The $\mathrm{pH}$ changed from neutral to acidic property. The acidic came from additional ion $\mathrm{H}$ (acid) from dissolution $\mathrm{HCl}$ compounds.

\section{CONCLUSION}

The research area is a rapidly developing area since ITERA was founded six years ago. To make the development of settlements more effective and efficient, it is necessary to conduct research on changes in groundwater facies and groundwater flow patterns. Based on this research, we concluded that the higher the elevation of the well, the lower the unconfined water table level. The unconfined groundwater chemistry is strongly influenced by weathering of silicate minerals and respiratory plants. The groundwater flows from SW to NE of research area. We suggest that the resident development should be concentrated in the NE part. The groundwater condition also needs to be monitored frequently. In addition, isotopes analysis to determine the age of groundwater is also should be considered to find the main recharge area.

\section{ACKNOWLEDGEMENTS}

Highest appreciation to Kemenristekdikti for their support through the Penelitian Dosen Pemula scheme (contract number: 007 / SP2H / LT / DRPM / 2018) for 2018 activities. The authors also expressed high appreciation to ITERA for permission and administration support during the research.

\section{REFERENCES}

Badan Standarisasi Nasional, 2008. Air dan air limbah - Bagian 58: Metoda pengambilan contoh air tanah.

Dhanwinder-singh, $\quad$ K.H.S.H., 2011. Geochemistry and assessment of hydrogeochemical processes in groundwater in the southern part of Bathinda district of Punjab , northwest India $1823-1833$. https://doi.org/10.1007/s12665-0110989-9

Edet, Anieken; Worden, R.H., 2009. Monitoring of the physical parameters and evaluation of the chemical composition of river and groundwater in Calabar (Southeastern Nigeria). Environ. Monit. Assess.

Esteller, M. V., Kondratenko, N., Expósito, J.L., Medina, M., Martin del Campo, M.A., 2017. Hydrogeochemical characteristics of a volcanic-sedimentary aquifer with special emphasis on $\mathrm{Fe}$ and $\mathrm{Mn}$ content: A case study in Mexico. J. Geochemical Explor. 180, 113-126. https://doi.org/10.1016/j.gexplo.2017.0 6.002

Gaillardet, J., Dupre, B., Louvat, P., Allegre, C.J., 1999. Global silicate weathering and $\mathrm{CO} 2$ consumption rates deduced from the chemistry of large rivers. Chem. Geol. 159, 3-30. https://doi.org/10.1016/S00092541(99)00031-5

Houston, U. of, 2001. web [WWW Document]. URL https://uh.edu/ geos6g/1330/weath.htm 1 (accessed 4.22.20).

Kut, K.M.K., Sarswat, A., Bundschuh, J., Mohan, D., 2018. Water as key to the Sustainable Development Goals of South Sudan - A water quality assessment of Eastern Equatoria State. Groundw. Sustain. Dev. https://doi.org/10.1016/j.gsd.2018.07.0 05

Mangga, S.A; Amirudin; Suwarti, T; Gafoer, S.S., 1993. Peta Geologi Lembar TanjungKarang, Sumatera. pp. 3-13. 
Meybeck, M., 1987. Global chemical weathering of surficial rocks estimated from river dissolved loads. Am. J. Sci. https://doi.org/10.2475/ajs.287.5.401

Pazand, K., Khosravi, D., Ghaderi, M.R., Rezvanianzadeh, M.R., 2018. Identification of the hydrogeochemical processes and assessment of groundwater in a semi-arid region using major ion chemistry: A case study of Ardestan basin in Central Iran. Groundw. Sustain. Dev. 6, 245-254. https://doi.org/10.1016/j.gsd.2018.01.0 08

Setiadi, H; Ruhijat, S., 1993. Hydrogeological Map, Tanjung Karang Sheet 1:250.000.

Siringoringo, L.P., Rizki, R., Nababan, J., 2019. Engineering , Environment , and Technology Hydrogeochemical and Groundwater Assessment for Drinking Purpose at ITERA Campus Area and Its Surroundings. J. Geosci. Eng. Environ. Technol. 04, 40-48. https://doi.org/10.25299/jgeet.2019.4.1. 2478

Yang, Q., Li, Z., Ma, H., Wang, L., Martín, J.D., 2016. Identification of the hydrogeochemical processes and assessment of groundwater quality using classic integrated geochemical methods in the Southeastern part of Ordos basin, China. Environ. Pollut. 218, 879-888. https://doi.org/10.1016/j.envpol.2016.0 8.017

Yudhoyono, S.B., 2011. Daftar cekungan airtanah di Indonesia.

Zaidi, F.K., Mogren, S., Mukhopadhyay, M., Ibrahim, E., 2016. Evaluation of groundwater chemistry and its impact on drinking and irrigation water quality in the eastern part of the Central Arabian graben and trough system, Saudi Arabia. J. African Earth Sci. 120, 208-219. https://doi.org/10.1016/j.jafrearsci.2016 .05 .012

Zhang, F., Jin, Z., Yu, J., Zhou, Y., Zhou, L., 2015. Hydrogeochemical processes between surface and groundwaters on the northeastern Chinese Loess Plateau:
Implications for water chemistry and environmental evolutions in semi-arid regions. J. Geochemical Explor. 159, 115-128. https://doi.org/10.1016/j.gexplo.2015.0 8.010 